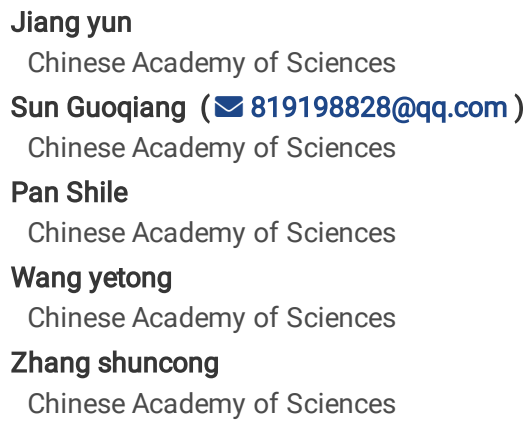

\title{
Sedimentary Environment Analysis of Eocene in Pingtai Area of Qaidam Basin, China
}




\section{Abstract}

The Pingtai area is a relatively new oil and gas exploration area in Qaidam Basin, China. As one of the most important sandstone reservoir in the Qaidam Basin, Eocene Lulehe Formation and Xiaganchaigou Formation. Based on the petrological characteristics and element geochemistry of core samples, the paleosalinity and paleoclimate changes are discussed. The results show that the clay mineral assemblage of the Lulehe Formation consists of smectite, chlorite, and illite; while the clay minerals in the Xiaganchaigou Formation consist of illite/smectite mixed layer, chlorite, and illite. The paleosalinity calculated using the $\mathrm{B}$ content and $\mathrm{Sr} / \mathrm{Ba}$ and $\mathrm{Rb} / \mathrm{Sr}$ ratios indicates that the Lulehe Formation was formed in a freshwater environment, and the Xiaganchaigou Formation was formed in alternating brackish water and fresh water environments. The chemical weathering index (CIA), La/Th ratio, and Eu anomaly index indicate that the overall chemical weathering in the Pingtai area was weak, the provenance was relatively stable, and the influence of diagenesis on the clay minerals and the trace element contents was negligible. From the Lulehe Formation to the Xiaganchaigou Formation, the paleoclimate gradually changed from warm and humid to cold with humid-dry seasonal changes, which is consistent with the global decrease in temperature in the Eocene. Moreover, because of the uplift of the Altun Mountain and the global cooling, the rainfall decreased, resulting in the Xiaganchaigou Formation being formed in a higher salinity environment.

\section{Introduction}

In recent years, with the development of geochemistry and sedimentology, the variations of paleosalinity and paleoclimate in different geological periods can be recognized through multiple geochemical parameters of sediments and clay minerals (Wei and Algeo 2019; Ye et al. 2016). Paleosalinity, which refers to the salinity of ancient water recorded in Paleosediments, can be used as an important indicator to analyze the characteristics of sedimentary environment in geological history (Degens et al. 1957; Harder 1970). The recovery of paleosalinity is an important way to reconstruction of paleoenvironments and further investigate the process and mechanism of environmental changes. The conventional paleosalinity reconstruction methods mainly include(Jiang et al. 2011; Kai et al. 1982; Walker and Price 1963; Walker 1968; Zheng and Liu 1999): qualitative analysis using fossil, mineralogy, and some geochemical parameters of sediments; quantitative calculation based on geochemical experiments; analysis and test on pore fluid and liquid inclusion. At present, geochemical analysis is the most commonly used method in the study of paleosalinity. The element decomposition and migration processes are affected with respect to the environmental conditions and element types, which results in the fact that element concentration varies in different environmental conditions. Therefore, the variation in content of certain elements in sediments can reflect the change of paleosalinity in the depositional period, e.g., the content of B and Na, the ratio of $\mathrm{Ba} / \mathrm{Ca}$ and B/Ga, as well as the carbon and oxygen isotopes (Couch 1971; Rohling and Eelco 2007; Seward 1978; Veizer et al. 1977).

Boron content is a very common parameter in paleosalinity and sedimentary environment study. Boron exists in seawater mainly as $\mathrm{B}(\mathrm{OH})_{3}$ and $\mathrm{B}(\mathrm{OH})^{4-}$, the relative abundances of which also depend on $\mathrm{pH}$ (Coca and Adiel 2016; Singh et al. 2014).the B contents of the clay minerals directly reflect the paleosalinity, and it is not affected by post-depositional processes (Yang et al. 2018; Ye et al. 2016). The ancient salinity based on B cannot only reflect the depositional environment, but it can also provide information about any climate change that occurred during the depositional period. Thus far, the method of reconstructing ancient salinity using the B contents of clay minerals has been applied to the study sediments developed at different times (F.Rose et al. 2000; Wei and Algeo 2019).

With the emphasis on global climate change research, the method of using clay minerals as a means of paleoclimate reconstruction has attracted the attention of scholars from worldwide. This method has been applied in numerous studies, such as studies of glacial polar regions(Zhao et al. 2005), plateau weathering products(Ding et al. 1998), lakes (Dera et al. 2008), and marine sediments(Cai et al. 2020). Clay minerals are widely distributed in various types of sediments, and their genesis is affected by many factors such as the source area lithology, mode of transport, paleoclimate, sedimentary environment, and diagenetic processes (Abdullayev and Leroy 2016; Fagel 2007; Fagel et al. 2003; Gylesjö and Arnold 2006; Hong et al. 2017; N. and D. 2020; Xu et al. 2016).Current studies have found when clay minerals are used to analyze paleoclimates, the results are consistent with those obtained using other methods (Gao et al. 2013; Liu et al. 2003). Furthermore, the wide distribution of clay minerals and the ease of sampling make clay minerals a particularly effective method for paleoclimate research(Jain and Tandon 2003). In this study, we will study the paleoclimate change during the sedimentary period through the paleosalinity value calculated by clay mineral assemblage and boron element.

\section{Geological setting}

The Qaidam Basin is the largest basin in the NE Tibetan Plateau (Dupont-Nivet et al. 2002; Molnar et al. 2010), with an average elevation of 2800m. It is surrounded by four mountain ranges with altitudes of 4000-5000 m(Fang et al. 2007a): the Qilian Mountains to the north, the Kunlun Mountains to the south, the Altun Mountains to the west, and the Ela Shan Mountains to the east(Zhang et al. 2013).The Tertiary sediments in Qaidam Basin started in Eocene and synchronized with the India Asia collision. The basement of the basin is composed of Precambrian Silurian metamorphic rocks and overlying Devonian Cenozoic sedimentary strata. Since the Paleocene, a large amount of detrital material has been transported into the Qaidam Basin from these nearby mountains due to thrusting and erosion (Chang et al. 2015), and the maximum thickness of the Cenozoic sediments is about $12000 \mathrm{~m}$. (Figure 1 )

The Pingtai area is located at the foot of the Qilian Mountains on the northern margin of the Qaidam Basin, belonging to a secondary structural unit in the northern margin of Qaidam Basin. The Qilian Mountain compression has a great influence on the platform area, which has the structural characteristics of thrust belt. The Jurassic sediments are not well developed in this area, and the Paleogene sediments are well developed. The Paleogene strata in this area is well developed and can be specifically divided into the Xiaganchaigou Formation and the Lulehe Formation(Fang et al. 2007b; Lu and Xiong 2009; Sun et al. 2005a). According to the lithostratigraphic framework, microfossils, magnetostratigraphy and isotopic chronology, the fault block belt in the northern margin of Qaidam basin developed from bottom to top in Cenozoic(Chang et al. 2015; Ji et al. 2017; Sun et al. 2005b; Xue et al. 2013) \the Lulehe Formation, 53.543.8 Ma, the Xiaganchaigou Formation, 43.8-35.5 Ma and the Shangganchaigou Formation,35.5-22 Ma.

Page 2/14 


\section{Samples And Methods}

The experimental samples mainly come from the drilling cores from well Ping 2 in the northern margin of the Qaidam Basin. The focus of the sample collection was to collect continuous whole-rock samples from the profile of the Xiaganchaigou Formation and from the entire Lulehe Formation. The sample collection depths were $644.77-653.26 \mathrm{~m}$ and $928.23-1002.78 \mathrm{~m}$. Before the trace element analyses, the samples were baked in an oven at $105^{\circ} \mathrm{C}$ for about 3 hours to remove moisture and to enable more accurate weighing, and then, the samples were dissolved in $\mathrm{HF}$ and $\mathrm{HNO}_{3}$ in sealed containers. Finally, they were analyzed using a laser ablation inductively coupled plasma mass spectrometer (LA-ICP-MS).

The data for the clay minerals were obtained by x-ray diffraction (XRD) analysis of the clay minerals $(<2 \mu \mathrm{m})$. An $\sim 1 \mathrm{~cm}^{3}$ sample was crushed (no grinding), soaked in deionized water for 24 hours, and $0.5 \%$ dilute hydrochloric acid was added to remove the $\mathrm{CaCO}_{3}$ until the pH test paper remained acidic after constant testing. The sample was allowed to settle naturally, and then, it was washed repeatedly with deionized water until the sample exhibited an antiflocculation effect. The sedimentation time was determined using the Stoke's law, and then, the $<2-\mu \mathrm{m}$ particles were removed using a syringe. They were precipitated using a centrifuge. Then, the sample was made into oriented thin sections using the scraping method, after which the slides were air-dried. The natural flakes remaining after the tests were soaked in saturated glycol steam for 24 hours to create glycol flakes. Finally, the tested flakes were heated in an oven at $490^{\circ} \mathrm{C}$ for $2 \mathrm{~h}$ to create heated flakes. The identification and interpretation of the clay minerals were mainly based on comprehensive comparisons of the XRD superimposed spectra obtained under three different testing conditions. The semi-quantitative calculation of each peak parameter was performed on the ethylene glycol curve using the MacDiff software. The calculation of the relative clay mineral content was mainly based on the area ratio of the diffraction peaks of the (001) crystal planes. The smectite (including random illite/smectite mixed layer minerals) calculation was based on the $1.7 \mathrm{~nm}(001) \mathrm{crystal}$ planes, and the illite was based on the $1 \mathrm{~nm}$ (001) crystal planes. Kaolinite (001) and chlorite (002) were based on the $0.7 \mathrm{~nm}$ superimposed peak (47), and their relative proportions were determined by fitting a peak area ratio of $0.357 / 10.354 \mathrm{~nm}$. The processing and testing of the trace elements and the XRD result of the samples were completed in the Key Laboratory of Oil and Gas Resources Research of Gansu Province.

\section{Results}

\section{Bulk mineralogy and Clay mineralogy}

By testing of core samples from the Pingtai area, 18 whole-rock components and 19 clay mineral components were obtained (Table 1 and Fig. 2,3). The XRD results show that the Xiaganchaigou Formation contains a small amount of dolomite and ankerite; while the Lulehe Formation hardly contains these two minerals. The overall quartz content of the Lulehe Formation is higher than that of the Xiaganchaigou Formation. In terms of the clay mineral content, the main clay minerals in the Lulehe Formation are smectite or illite/smectite mixed layers (I/S), followed by illite and chlorite. The relative content of smectite is $29-70 \%$, with an average of $49.3 \%$. The relative content of illite is $7-32 \%$, with an average of $16.4 \%$; and the relative content of chlorite is $7-45 \%$, with an average of $23.7 \%$. The clay minerals of the Xiaganchaigou Formation are mainly illite/smectite mixed-layers, followed by illite and chlorite. The relative content of $\mathrm{I} / \mathrm{S}$ is $35-77 \%$, with an average of $66.82 \%$. Except for the first rock sample, it is basically greater than $55 \%$. The relative content of illite is $4-29 \%$, with an average of $14.9 \%$; and the relative content of chlorite is $14-20 \%$, with an average of $16.7 \%$. The clay minerals in the Xiaganchaigou Formation and in the Lulehe Formation do not include kaolinite and chlorite/smectite mixed-layers. The clay mineral content changes but the illite and chlorite contents are basically similar in the vertical distribution, They are the direct products of the weak chemical weathering of the parent rock, and their relative contents are also close. 
Table 1

The whole rock composition of the Pingtai area

\begin{tabular}{|c|c|c|c|c|c|c|c|c|c|}
\hline Sample & deep & formation & quartz & Potassium feldspar & plagioclase & calcite & dolomite & ankerite & anhydrite \\
\hline 14 & 644.77 & $E_{3}$ & 15.4 & 0.5 & 3.4 & 16.6 & 9.7 & 13.8 & 2.4 \\
\hline 16 & 645.77 & $E_{3}$ & 31.9 & 1 & 7.1 & 10.8 & 1.6 & 2.4 & 2.8 \\
\hline 17 & 647.76 & $E_{3}$ & 47.5 & 2.3 & 11.2 & 18 & 3 & - & 1.6 \\
\hline 18 & 648.26 & $E_{3}$ & 26.9 & 1 & 6.5 & 22.7 & 3.9 & 6.5 & 1.9 \\
\hline 19 & 648.76 & $E_{3}$ & 18.2 & 0.4 & 3.7 & 28.4 & 2.4 & 6.8 & 2.1 \\
\hline 20 & 649.76 & $E_{3}$ & 40.7 & 1.4 & 11.7 & 23.9 & 1.4 & 1.1 & 2.7 \\
\hline 22 & 650.26 & $E_{3}$ & 56.5 & 1.9 & 11.4 & 9.5 & 1.2 & 0.6 & 0.9 \\
\hline 24 & 651.26 & $E_{3}$ & 42.8 & 0.9 & 8.5 & 27.2 & 2 & 1.8 & 1.9 \\
\hline 26 & 652.26 & $E_{3}$ & 42.8 & 1.4 & 9.1 & 20.9 & 1.8 & 1.2 & 2.1 \\
\hline 28 & 653.26 & $E_{3}$ & 36.8 & 1.3 & 9.4 & 23.2 & 2.1 & 1.4 & 2.6 \\
\hline 52 & 928.23 & $E_{1+2}$ & 70.5 & 1.5 & 9.6 & 9.5 & - & - & 1 \\
\hline 55 & 929.68 & $E_{1+2}$ & 60.8 & 6.6 & 15.6 & 4.8 & 0.5 & 0.6 & 1.7 \\
\hline 60 & 995.8 & $E_{1+2}$ & 64.5 & 2.3 & 8.3 & 18.8 & - & - & 1.2 \\
\hline 63 & 997.3 & $E_{1+2}$ & 67.9 & 3.1 & 12.3 & 8.1 & - & - & 0.7 \\
\hline 65 & 998.28 & $E_{1+2}$ & 50.3 & 3.1 & 12.3 & 22.9 & - & - & 1.8 \\
\hline 70 & 1000.88 & $E_{1+2}$ & 58.8 & 3.8 & 15.8 & 11.2 & 0.3 & 0.7 & 1.8 \\
\hline 73 & 1002.28 & $\mathrm{E}_{1+2}$ & 31.5 & 1.6 & 6.4 & 13.1 & - & - & 3 \\
\hline 74 & 1002.78 & $E_{1+2}$ & 47.6 & 2 & 13.3 & 8.1 & - & - & 1.9 \\
\hline
\end{tabular}

\section{Paleosalinity}

\section{Equivalent B derived paleosalinity}

The equivalent B content is a standard proposed by Wallker (1968) and Price (1963) to evaluate paleosalinity. Among the clay minerals, illite has the strongest $\mathrm{B}$ absorption capacity, so this method is only suitable for ancient salinity calculations based on illite. The $\mathrm{B}$ content of the illite in clays is proportional to the content of $\mathrm{K}_{2} \mathrm{O}$. After standardization, the $\mathrm{B}$ content related to a given $\mathrm{K}_{2} \mathrm{O}$ content $(5 \%)$ is called the equivalent $\mathrm{B}$ content. The corrected $\mathrm{B}$ content is converted into the adjusted $\mathrm{B}$ content(Walker 1968). The formula used for this conversion is adjusted boron $=8.5 \times \mathrm{B} / \mathrm{K}_{2} \mathrm{O}$. The equivalent $\mathrm{B}$ content can be obtained by projecting the corrected $\mathrm{B}$ and $\mathrm{K}_{2} \mathrm{O}$ onto a dispersion curve constructed from the experimental data (Fig. 4). The equivalent $\mathrm{B}$ content of the Xiaganchaigou Formation in the Pingtai area is 102-203 ppm, with an average of 165.73 ppm; and that of the Lulehe Formation's content is $40-175$ ppm, with an average of 96 ppm. Under normal circumstances, the equivalent B content is 300-400 ppm in a normal marine environment, 200-300ppm in a brackish water environment, and less than 200 ppm in a freshwater environment. It was found that in the Pingtai area, the equivalent B content is predominantly less than 200 ppm, which indicates that the strata were deposited in a freshwater environment.

\section{Couch's paleosalinity}

The main disadvantage of the equivalent B method is that the accuracy of its calculation largely depends on the abundance of illite and other clay minerals in the sample. Because of the different combinations of clay minerals in geological samples, each clay mineral has a different $B$ absorption capacity. Couch used the $B$ in kaolinite to further correct the boron content $\left(\left(\right.\right.$ Couch 1971)). The equation used for this correction is kaolinite boron $=B_{k} /\left(4 X_{i}+2 X_{m}+X_{k}\right)$, where $X_{i}$ is the illite content, $X_{m}$ is the smectite content, and $X_{k}$ is the kaolinite content.

Couch's paleosalinity calculation equation is $\lg ($ kaolinite boron $)=1.28 \times \operatorname{lgSp}+0.11$, where $\mathrm{Sp}$ is paleosalinity. In the past, scholars have divided paleosalinity into three types: paleosalinities of $<10 \%$ is slightly freshwater-slightly saline water type; paleosalinities of $10 \%$ o- $18 \%$ o are brackish water type; and paleosalinities of $>18 \%$ ore salt water type. The average paleosalinity of the Xiaganchaigou Formation in the Pingtai area is $10.13 \%$, and that of the Lulehe Formation is $6.26 \%$ o (Table 2). The changes in Couch's paleosalinity value in the Pingtai area are very similar to the changes in the equivalent B content. These two ancient salinity calculation methods have a relatively high positive correlation (Fig. 5), indicating that these methods are highly reliable. 
Table 2

Data of clay minerals analysis and paleosalinity calculation in the Pingtai area

\begin{tabular}{|c|c|c|c|c|c|c|c|c|c|c|c|c|c|c|c|}
\hline sample & depth & formation & $S$ & I/S & I & C & $\mathrm{I} / \mathrm{S}$ & $\mathrm{S}^{\#}$ & $I^{\#}$ & $\begin{array}{l}B\left(10^{-}\right. \\
6)\end{array}$ & $\begin{array}{l}\text { Equivalent } \\
\text { boron }\end{array}$ & $\begin{array}{l}\text { Adams } \\
\text { paleosalinity }\end{array}$ & $\begin{array}{l}\text { Couch } \\
\text { paleosalinity }\end{array}$ & $\mathrm{Ga}$ & $\mathrm{B} / \mathrm{Ga}$ \\
\hline 14 & 644.77 & $E_{3}$ & 26 & 35 & 22 & 17 & 23 & 34.05 & 48.95 & 58.17 & 150 & 7.61 & 9.1 & 15.61 & 3.73 \\
\hline 16 & 645.77 & $E_{3}$ & - & 69 & 14 & 17 & 63 & 43.47 & 39.53 & 93.72 & 203 & 12.79 & 14.16 & 20.39 & 4.6 \\
\hline 17 & 647.76 & $E_{3}$ & - & 76 & 4 & 20 & 53 & 40.28 & 39.72 & 56.9 & 160 & 8.59 & 9.77 & 14.34 & 3.97 \\
\hline 18 & 648.26 & $E_{3}$ & - & 71 & 13 & 16 & 53 & 37.63 & 46.37 & 54.64 & 156 & 8.2 & 8.91 & 14.52 & 3.76 \\
\hline 19 & 648.76 & $E_{3}$ & - & 72 & 14 & 14 & 56 & 40.32 & 45.68 & 62.06 & 165 & 9.08 & 9.55 & 15.92 & 3.9 \\
\hline 20 & 649.76 & $E_{3}$ & - & 69 & 14 & 17 & 54 & 37.26 & 45.74 & 68.72 & 195 & 12.01 & 10.96 & 14.35 & 4.79 \\
\hline 22 & 650.26 & $E_{3}$ & - & 69 & 13 & 18 & 57 & 39.33 & 42.67 & 71.56 & 175 & 10.05 & 11.3 & 18.88 & 3.79 \\
\hline 25 & 651.76 & $E_{3}$ & - & 72 & 11 & 17 & 56 & 40.32 & 42.68 & 69.81 & 174 & 9.96 & 11.01 & 17.14 & 4.07 \\
\hline 26 & 652.26 & $E_{3}$ & - & 69 & 15 & 16 & 56 & 38.64 & 45.36 & 37.57 & 102 & 2.92 & 6.64 & 15.93 & 2.36 \\
\hline 28 & 653.26 & $E_{3}$ & - & 56 & 29 & 15 & 59 & 33.04 & 51.96 & 66.67 & 165 & 9.08 & 9.93 & 12.85 & 5.19 \\
\hline 52 & 928.23 & $\mathrm{E}_{1+2}$ & 70 & 0 & 18 & 12 & 0 & 70.07 & 17.93 & 47.45 & 175 & 10.05 & 9.31 & 8.73 & 5.44 \\
\hline 55 & 929.68 & $\mathrm{E}_{1+2}$ & 63 & 0 & 14 & 23 & - & 63 & 14 & 14.51 & 42 & - & 4.15 & 9.76 & 1.49 \\
\hline 58 & 931.28 & $\mathrm{E}_{1+2}$ & 29 & 0 & 32 & 39 & - & 29 & 32 & - & - & - & - & - & - \\
\hline 60 & 995.8 & $E_{1+2}$ & 68 & 0 & 19 & 13 & 0 & 68.08 & 18.92 & 33.11 & 140 & 6.64 & 7.03 & 7.55 & 4.39 \\
\hline 63 & 997.3 & $E_{1+2}$ & 68 & 0 & 12 & 20 & - & 68 & 12 & 24.39 & 100 & 2.73 & 6.18 & 8.79 & 2.77 \\
\hline 65 & 998.28 & $\mathrm{E}_{1+2}$ & 34 & 0 & 21 & 45 & - & 34 & 21 & 14.62 & 50 & - & 4.81 & 10.22 & 1.43 \\
\hline 70 & 1000.88 & $E_{1+2}$ & 32 & 0 & 28 & 40 & - & 32 & 28 & 12.99 & 40 & - & 3.91 & 9.71 & 1.34 \\
\hline 75 & 1114.4 & $\mathrm{E}_{1+2}$ & 70 & 13 & 10 & 7 & 5 & - & - & - & - & - & - & - & - \\
\hline 76 & 1116.76 & $E_{1+2}$ & 70 & 0 & 16 & 14 & 0 & 69.52 & 16.48 & 40.64 & 125 & 5.17 & 8.46 & 13.13 & 3.09 \\
\hline
\end{tabular}

(S represents montmorillonite, I represents illite, C represents chlorite, $\mathrm{S}^{\#}$ represents the content of montmorillonite after correction, and I\# represents the content of illite after correction)

\section{Trace element results}

The Sr/Ba ratio can also be used as an important indicator of paleosalinity(Gang et al. 2018), and it is positively correlated with paleosalinity. The principle of using $\mathrm{Sr} / \mathrm{Ba}$ for paleosalinity reconstruction is based on the difference between the behaviors of $\mathrm{Sr}$ and $\mathrm{Ba}$. That is they are separated by their geochemical behaviors in sedimentary environments. Since the migration ability of $\mathrm{Sr}$ is stronger than that of $\mathrm{Ba}$, the $\mathrm{Ba}^{2+}$ carried by terrestrial material is the first to combine with the $\mathrm{SO}_{4}{ }^{2-}$ in the lake to form $\mathrm{BaSO}_{4}$ precipitates, causing the $\mathrm{Sr} / \mathrm{Ba}$ value to gradually increase as it moves away from the coast. The ratio can be qualitatively reflect the paleosalinity(Rongcai and Meiqing 1999). The classification standard is as follows: $\mathrm{Sr} / \mathrm{Ba}<0.5$ indicates brackish water, $0.5<$ $\mathrm{Sr} / \mathrm{Ba}<1$ indicates a brackish lake, $\mathrm{Sr} / \mathrm{Ba}>1$ indicates a salt water environment(Dera et al. 2011). Overall, the Sr/Ba ratio in the Pingtai area gradually increases from bottom to top. The Sr/Ba values of the Lulehe Formation are $0.16-0.50$, with and average value of 0.30 , which indicates a freshwater environment. The Sr/Ba values of the Xiaganchaigou Formation are $0.43-1.40$, with an average value of 0.73 . Most of the sample values are around 0.5 , indicating a freshwater-brackish water environment. The paleosalinity of the Xiaganchaigou Formation is significantly higher than that of the Lulehe Formation.

$\mathrm{B}$ and $\mathrm{Ga}$ have different properties during deposition. The Ga content in the freshwater environment is higher than that in a marine environment, which is in sharp contrast to the enrichment of $\mathrm{B}$ in a marine environment. Therefore, the B/Ga ratio is often used as an important indicator of paleosalinity(He et al. 2017). B/Ga ratios of $<4$ indicate fresh water, while ratios of $>7$ indicate sea water (Ma et al., 2016). The B/Ga values of the Lulehe Formation are 1.34-5.44, with an average of 2.85; and those of the Xiaganchaigou Formation are 2.36-5.19, with an average of 4.07. Thus, the paleosalinity of the depositional environment of the Xiaganchaigou Formation was higher than that of the Lulehe Formation, which is consistent with the conclusions drawn from their Sr/Ba ratios (Fig. 6).

The correlation between $\mathrm{Rb} / \mathrm{Sr}$ ratio and the intensity of the water flow into the lake is relatively significant(Xu et al. 2010), so the $\mathrm{Rb} / \mathrm{Sr}$ ratio corresponds to changes between dry and wet paleoclimate conditions. in continental basins, under wet conditions, chemical weathering is strong. Rb has a large ion radius, so it is very soluble and filters out of the parent minerals. Then, it is adsorbed by clays. However, these clays do not remain in place, and most of them are transported into lake sediments due to denudation(Ingram and Sloan 1992). At the same time, the dissolved Sr element that enters the lake basin is generally 
deposited during the dry, so the $\mathrm{Rb} / \mathrm{Sr}$ ratio is high in the humid environment. Therefore, in terrestrial basins, the meaning of the $\mathrm{Rb} / \mathrm{Sr}$ ratio is actually the opposite of that under marine conditions, that is, a high $\mathrm{Rb} / \mathrm{Sr}$ ratio represents a humid climate and a low $\mathrm{Rb} / \mathrm{Sr}$ ratio represents an arid climate. The $\mathrm{Rb} / \mathrm{Sr}$ values of the Lulehe Formation are $0.31-0.44$, with an average of 0.38 ; and those of the Xiaganchaigou Formation are $0.13-0.55$, with an average of 0.32 .

\section{Discussion}

\section{Diagenesis}

The trace element contents of clastic sedimentary rocks are comprehensively affected by the mineral composition of their parent rocks, weathering and transportation processes, sedimentary environment, and post-sedimentary diagenesis. The older the rock, the greater the influence of fluid diagenesis in the later period. However, based on the analysis of the whole rock compositions and burial depths in the Pingtai area, the burial depth is relatively shallow, and the core samples contain almost no diagenetic minerals, such as dolomite and iron dolomite. Therefore, the influence of diagenesis on these rocks was weak, which is not conducive to the conversion of smectite to illite during rock formation(Chamley 1994).

The intensity of the chemical weathering of the rocks in the source area can be determined using the chemical weathering index (CIA) of the fine-grained debris (Nesbitt and Young 1982). $\mathrm{ClA}=100 \times \mathrm{Al}_{2} \mathrm{O}_{3} /\left(\mathrm{Al}_{2} \mathrm{O}_{3}+\mathrm{CaO}+\mathrm{Na}_{2} \mathrm{O}+\mathrm{K}_{2} \mathrm{O}\right)$, where both are in mole percentages. The stronger the chemical weathering of the rocks in the source area, the higher the CIA value. When the CIA value is 50 , the source area has not experienced chemical weathering(Goldberg and Humayun 2010). The CIA value of the Xiaganchaigou Formation is 46.83 , and that of the Lulehe Formation is 46.65 (Table 3 ), indicating that the chemical weathering index in the Pingtai area is low and the source area did not experience significant chemical weathering. Chlorite can only remain in areas where chemical weathering is inhibited, which is consistent with the results indicated by the CIA index. Changes in provenance can cause changes in the B content during the transportation process and changes in the types and contents of the clay minerals present. Among the rare earth elements, Th and Sc are geochemically insensitive to chemical weathering and fractionation, and their ratios hardly change during migration and deposition(Mclennan et al. 1993).

Table 3

Content of main and trace elements in Pingtai area

\begin{tabular}{|c|c|c|c|c|c|c|c|c|c|c|c|c|c|}
\hline Sample & deep & formation & $\mathrm{K}_{2} \mathrm{O} \%$ & $\mathrm{Na}_{2} \mathrm{O} \%$ & $\mathrm{Al}_{2} \mathrm{O}_{3} \%$ & $\mathrm{MgO} \%$ & $\mathrm{CaO} \%$ & CIA & $\mathrm{Rb}$ & $\mathrm{Sr}$ & $\mathrm{La}$ & Th & $\mathrm{Ba}$ \\
\hline 14 & 644.77 & $E_{3}$ & 2.79 & 0.92 & 12.82 & 8.67 & 18.97 & 36.11 & 106.10 & 603.14 & 26.85 & 10.28 & 447.41 \\
\hline 16 & 645.77 & $E_{3}$ & 3.48 & 1.20 & 17.30 & 5.71 & 6.43 & 60.89 & 94.98 & 275.48 & 30.03 & 12.52 & 506.21 \\
\hline 17 & 647.76 & $E_{3}$ & 2.25 & 1.63 & 13.29 & 3.80 & 9.49 & 49.85 & 84.53 & 241.51 & 29.25 & 9.33 & 420.49 \\
\hline 18 & 648.26 & $E_{3}$ & 2.44 & 1.10 & 12.23 & 6.32 & 17.35 & 36.93 & 88.98 & 669.95 & 34.57 & 8.28 & 475.25 \\
\hline 19 & 648.76 & $E_{3}$ & 2.62 & 1.03 & 12.64 & 4.85 & 19.94 & 34.89 & 85.21 & 457.44 & 30.18 & 8.13 & 423.39 \\
\hline 20 & 649.76 & $E_{3}$ & 2.32 & 1.24 & 12.32 & 3.29 & 15.73 & 38.98 & 76.19 & 252.86 & 29.64 & 8.39 & 401.22 \\
\hline 22 & 650.26 & $E_{3}$ & 2.76 & 1.66 & 16.18 & 4.23 & 4.46 & 64.57 & 102.98 & 186.30 & 34.62 & 12.51 & 486.25 \\
\hline 24 & 651.26 & $E_{3}$ & 2.72 & 1.20 & 13.99 & 3.74 & 12.64 & 45.79 & 81.61 & 255.99 & 34.93 & 9.16 & 468.11 \\
\hline 25 & 651.76 & $E_{3}$ & & & & & & & 91.61 & 283.50 & 31.08 & 9.25 & 510.60 \\
\hline 26 & 652.26 & $E_{3}$ & 2.80 & 1.42 & 15.08 & 4.29 & 9.69 & 52.02 & 97.07 & 225.85 & 31.81 & 10.43 & 472.25 \\
\hline 28 & 653.26 & $E_{3}$ & 2.58 & 1.43 & 14.09 & 3.69 & 11.05 & 48.34 & 76.65 & 203.10 & 32.30 & 9.30 & 469.37 \\
\hline 52 & 928.23 & $E_{1+2}$ & 1.68 & 1.68 & 9.42 & 1.45 & 8.14 & 45.03 & 60.90 & 139.25 & 24.13 & 7.48 & 465.93 \\
\hline 55 & 929.68 & $\mathrm{E}_{1+2}$ & 2.38 & 3.08 & 11.54 & 0.95 & 4.31 & 54.15 & 91.58 & 243.71 & 12.68 & 4.22 & 1333.97 \\
\hline 58 & 931.28 & $\mathrm{E}_{1+2}$ & & & & & & & 88.12 & 230.02 & 15.28 & 4.98 & 869.87 \\
\hline 60 & 995.80 & $E_{1+2}$ & 1.50 & 1.87 & 7.95 & 1.01 & 10.59 & 36.28 & 53.23 & 132.27 & 19.60 & 6.11 & 531.37 \\
\hline 63 & 997.30 & $E_{1+2}$ & 1.73 & 2.55 & 10.16 & 1.36 & 5.42 & 51.16 & 61.85 & 185.69 & 21.53 & 7.70 & 482.28 \\
\hline 65 & 998.28 & $E_{1+2}$ & 1.90 & 2.71 & 10.64 & 0.93 & 7.67 & 46.42 & 74.09 & 233.87 & 13.99 & 4.39 & 1442.84 \\
\hline 70 & 1000.88 & $\mathrm{E}_{1+2}$ & 2.29 & 2.67 & 10.61 & 0.86 & 7.45 & 46.09 & 84.49 & 227.13 & 12.97 & 4.16 & 622.13 \\
\hline 76 & 1116.76 & $E_{1+2}$ & 2.30 & 0.96 & 13.46 & 3.05 & 11.65 & 47.44 & 95.48 & 216.67 & 33.08 & 10.41 & 431.11 \\
\hline
\end{tabular}

The La/Th ratio and Eu anomalies (Eu/Eu*) are usually regarded as provenance indicators(Cullers et al. 1988). In the Pingtai area, the La/Th and Eu/Eu* ratios exhibit stable changes with limited variability. These ratios are also close to their respective upper continental crust (UCC) values, indicating that the 
impact of the provenance was negligible. Based on these results and the CIA, the clay mineral contents of the Lulehe Formation and the Xiaganchaigou Formation in the Pingtai area were less affected by the provenance area and the clay minerals produced during chemical weathering. Therefore, trace elements and clay minerals can be effectively used in paleoenvironment reconstruction.

\section{Paleosalinity and clay minerals}

The types and their combinations of the clay minerals in sediments are closely related to the climatic conditions under which they were deposited. When the climatic conditions change, a suitable combination of clay minerals will be formed(Liu et al. 2020; Rodrigues et al. 2018). Studies have shown that illite and chlorite are generally formed in dry and cold climates(Wang et al. 2020); smectite is usually formed in warm and humid climates as a weathering product of alkali-neutral volcanic rocks, metamorphic rock minerals, and the low-temperature self-generating rock minerals of the weathering products(Taheri et al. 2019). The formation of smectite is related to an enhanced degree of hydrolysis. Relatively warm and humid climatic conditions are conducive to the formation of smectite, and its content decreases as the climate becomes warmer. Illite/smectite mixed layers clay minerals are formed under seasonal dry and humid climatic conditions(Jain and Tandon 2003). In this study, the clay minerals in most of the samples from the Lulehe Formation were dominated by smectite, reflecting relative warm and humid climate conditions. Among them, three samples were dominated by illite/smectite mixed layers; however, the smectite content is as high as $91,92,88$ in the illite/smectite mixed layers, indicating that the clay mineral content is actually dominated by smectite, and it is believed that the climate during the deposition of the Lulehe Formation was mainly warm and humid. The clay minerals in the Xiaganchaigou Formation mainly consist of illite/smectite mixed layers, indicating that the climate had entered an alternating wet and dry phase during the deposition of this part of the formation, but it is mainly cold and dry with small fluctuations. The ubiquitous illite/smectite mixed layers in the Oligocene strata in the Linxia Basin reflect the relatively small fluctuations in climate (Hong et al. 2007). From the Lulehe Formation to the Xiaganchaigou Formation, the paleosalinity changed from a freshwater environment to a brackish water environment, which was caused by this climate change. Chlorite can generally only be preserved in areas where chemical weathering is inhibited. The previous finding that chlorite is widespread in these two formations is with the results obtained using the CIA index.

\section{Paleoclimate analysis}

According to the comprehensive judgment of the above major trace elements and clay minerals, the paleoclimate of Lulehe formation is mainly warm and humid, while that of Xiaganchaigou formation is mainly cold and dry, supplemented by seasonal humidity. The paleosalinity of Lulehe formation to Xiaganchaigou formation has changed from fresh water environment to brackish water environment. The causes of the above paleosalinity and paleoclimate changes will be analyzed from two aspects of climate and structure In the early Eocene, due to the collision of Eurasian plate, the Qaidam Basin moved northward slowly, resulting in the increase of latitude and altitude (Zhang et al. 2018), making the Qaidam Basin in a subtropical arid area (Sun and Wang 2005). It is generally believed that the uplift amplitude of the Qinghai Tibet Plateau during the deposition of the Lulehe formation in the Eocene was small enough to affect the atmospheric circulation (Coleman and Hodges 1995; Harrison et al. 1992); Harrison et al Climate change is mainly affected by westerly belt (Chamberlain et al. 2015). Combined with the latest research on leaf fossil evidence of Qaidam, westerly belt dominated climate before early Oligocene (Song et al. 2020). At the same time, the Altyn Mountains are at a low altitude, and the westerly zone is easy to enter the Qaidam Basin from the subtropical zone. Under the above conditions, the warm and humid climate of the middle Lulehe formation in this study is completely consistent with the climatic environment at that time. Combined with previous studies, chemical differentiation index CIW value (Song et al. 2013)and clay mineral assemblage dominated by montmorillonite(Hong et al. 2010) in Dahonggou section of northern Qaidam Basin, as well as pine and xerophyte show stable low sporopollen values. These evidences provide potential support for the interpretation of climate change in the region. After the middle Eocene climate, global cooling led to the southward migration of westerlies(Li et al. 2017), weakening the water vapor transport to the eastern Qaidam Basin. A significant decrease in temperature may result in a strong decrease in seawater evaporation at the water source(Bosboom et al. 2014; Ye et al. 2016). Specifically, relatively higher temperature will promote seawater evaporation and produce higher humidity. This water can be transported to the Qaidam basin to promote rainfall and fresh water solute supply. On the contrary, lower temperature will weaken the evaporation of seawater at the water source, resulting in lower water vapor content and relatively arid climate. At the same time, because the Hongsanhan thrust fold belt of Altun Mountain fault was formed at about $40 \mathrm{Ma}$ (Wu et al. 2013 ), it may block the movement of some water, and eventually lead to the high salinity of Xiaganchaigou formation in the platform area, and the moist drought fluctuation of Xiaganchaigou formation may also be attributed to the balance between evaporation and precipitation, which may be related to the suspicious climate driven by orbital cycle(Abels et al. 2011; Xiao et al. 2010). In continental basins, the deposition and dissolution of calcite mainly depend on the saturation of calcium carbonate. Higher rainfall will lead to lower concentrations of calcium and cobalt ions in water, which is conducive to the dissolution of calcite. On the contrary, lower rainfall resulted in increased concentrations of calcium and carbon dioxide in water due to lower flow, and promoted the deposition of calcite(Hong et al. 2007). The high calcite content and salinity of Xiaganchaigou formation support this view. The main reason for this climate is global cooling, followed by the uplift of Altun mountain.

\section{Conclusions}

Through the study of the clay mineralogy and geochemistry of the strata the Pingtai area of the Qaidam Basin, it was found that during the Lulehe FormationXiaganchaigou Formation period, the clay mineral composition transitioned from smectite dominated to illite/smectite mixed layer dominated, but the chlorite and illite contents did not change significantly. This reflects the fact that at this time, the climate changed from warm and humid to cold and dry with seasonal humidity. This cooling event is consistent with the global climate. Owing to the uplift of the Altun Mountain and the continuous cooling of the climate during the Eocene, the water supply in the inland areas decreased and the rainfall decreased, resulting in a transformation in paleosalinity from a freshwater sedimentary environment to a brackish water sedimentary environment. The average paleosalinity reached $10.13 \%$ o during the Xiaganchaigou Formation period. The paleosalinity is not only conducive to evaluating the sedimentary environment at this time, but it also provided support for the climate change that occurred during this period. 


\section{Declarations}

\section{Acknowledgments}

This work was financially supported by the National Natural Foundation of China(Grant No.41872145), the Natural Science Foundation of Gansu Province(Grant No.17JR5RA293), and a Key Laboratory Project of Gansu Province(Grant No.1309RTSA041)

\section{References}

1. Abdullayev E, Leroy SAG (2016) Provenance of clay minerals in the sediments from the Pliocene Productive Series, western South Caspian Basin. Acta Crystallogr A 73:517-527

2. Abels HA, Dupont-Nivet G, Xiao G, Bosboom R, Krijgsman W (2011) Step-wise change of Asian interior climate preceding the Eocene-Oligocene Transition (EOT). Palaeogeography Palaeoclimatology Palaeoecology 299:399-412

3. Bosboom RE, Abels HA, Hoorn C, Van dB, Guo ZJ, Dupont-Nivet G (2014) Aridification in continental Asia after the Middle Eocene Climatic Optimum (MECO). Earth Planetary Science Letters 389:34-42

4. Cai G, Li S, Zhong AZ, Chen L H (2020) Clay minerals, Sr-Nd isotopes and provenance of sediments in the northwestern South China Sea. Journal of Asian Earth Ences 202:104531

5. Chamberlain PC, Mulch, Andreas, Sjostrom, Derek J, Winnick MJ, Graham SA (2015) Role of the westerlies in Central Asia climate over the Cenozoic. Earth and Planetary Science Letters: A Letter Journal Devoted to the Development in Time. of the Earth Planetary System 428:33-43

6. Chamley H (1994) Clay Mineral Diagenesis. Springer Netherlands

7. Chang H, Li L, Qiang X, Garzione CN, Pullen A, An Z (2015) Magnetostratigraphy of Cenozoic deposits in the western Qaidam Basin and its implication for the surface uplift of the northeastern margin of the Tibetan Plateau. Earth Planetary Science Letters 430:271-283

8. Coca A (2016) Boron Chemistry: An Overview, 1-25 pp

9. Coleman M, Hodges K (1995) Evidence for Tibetan plateau uplift before 14 Myr ago from a new minimumage for east-west extension. Nature 374:49-52

10. Couch EL (1971) Calculation of paleosalinities from boron and clay mineral data. Aapg Bulletin 55:1829-1837

11. Cullers RL, Basu A, Suttner LJ (1988) Geochemical signature of provenance in sand-size material in soils and stream sediments near the Tobacco Root batholith, Montana, U.S.A. Chemical Geology 70:335-348

12. Degens ET, EGWM L, Keith ML (1957) Environmental Studies of Carboniferous Sediments Part I: Geochemical Criteria for Differentiating Marine from Fresh-Water Shales. AAPG Bull 41:2427-2455

13. Dera G, Pellenard P, Neige P, Deconinck J-F, Pucéat E, Dommergues J-L (2008) Distribution of clay minerals in Early Jurassic Peritethyan seas: Palaeoclimatic significance inferred from multiproxy comparisons. Palaeogeogr Palaeoclimatol Palaeoecol 271:39-51

14. Dera G, Pellenard P, Neige P, Deconinck J-F, Pucéat E, Dommergues J-L (2011) Discussion of sedimentary environment and its geological enlightenment of Shanxi Formation in Ordos Basin. Acta Petrologica Sinica 27:2213-2229

15. Ding ZL, Sun JM, Liu TS, Zhu RX, Yang SL, Guo B (1998) Wind-blown origin of the Pliocene red clay formation in the central Loess Plateau, China. Earth Planetary Science Letters 161:135-143

16. Dupont-Nivet G, Butler RF, Yin A, Chen X (2002) Paleomagnetism indicates no Neogene rotation of the Qaidam Basin in northern Tibet during Indo-Asian collision. Geology 30:263

17. Chaussidon FRoseE, France-Lanord M C (2000) Fractionation of boron isotopes during erosion processes: the example of Himalayan rivers. Geochimica Et Cosmochimica Acta 64:397-408

18. Fagel N (2007) Chapter Four Clay Minerals, Deep Circulation and Climate. Elsevier Science \& Technology

19. Fagel N, Boski T, Likhoshway L, Oberhaensli H (2003) Late Quaternary clay mineral record in Central Lake Baikal (Academician Ridge, Siberia). Palaeogeography Palaeoclimatology Palaeoecology 193:159-179

20. Fang X, Zhang W, Meng Q (2007a) High-resolution magnetostratigraphy of the Neogene Huaitoutala section in the eastern Qaidam Basin on the NE Tibetan Plateau, Qinghai Province, China and its implication on tectonic uplift of the NE Tibetan Plateau. Earth Planetary ence Letters 258:293-306

21. Fang X, Zhang W, Meng Q, Junping (2007b) High-resolution magnetostratigraphy of the Neogene Huaitoutala section in the eastern Qaidam Basin on the NE Tibetan Plateau, Qinghai Province, China and its implication on tectonic uplift of the NE Tibetan Plateau. Earth Planetary ence Letters 258:293-306

22. Gang W, XieQin Y, Qin Y, Wang J, Shen J, Han B, Liang C, Wang Q (2018) Element geochemical characteristics and formation environment for the roof, floor and gangue of coal seams in the Gujiao mining area, Xishan coalfield, China. Journal of Geochemical Exploration Journal of the Association of Exploration Geochemists 190:336-344

23. Gao Y, Wang C, Liu Z, Zhao B, Zhang X (2013) Clay mineralogy of the middle Mingshui Formation (upper Campanian to lower Maastrichtian) from the SKIn borehole in the Songliao Basin, NE China: Implications for palaeoclimate and provenance. Palaeogeography Palaeoclimatology Palaeoecology 385:162-170

24. Goldberg K, Humayun M (2010) The applicability of the Chemical Index of Alteration as a paleoclimatic indicator: An example from the Permian of the Paraná Basin, Brazil. Palaeogeography Palaeoclimatology Palaeoecology 293:175-183

25. Gylesjö S, Arnold E (2006) Clay mineralogy of a red clay-loess sequence from Lingtai, the Chinese Loess Plateau. Global Planetary Change 51:181-194 26. Harder $\mathrm{H}$ (1970) Boron content of sediments as a tool in facies analysis. Sed Geol 4:153-175 
27. Harrison TM, Copeland P, Kidd W, Yin AN (1992) Raising Tibet. Science 255:1663-1670

28. He J, Ding W, Jiang Z, Jiu K, Li A, Sun Y (2017) Mineralogical and chemical distribution of the Es3L oil shale in the Jiyang Depression, Bohai Bay Basin (E China): Implications for paleoenvironmental reconstruction and organic matter accumulation. Marine Petroleum Geology 81:196-219

29. Hong H, Fang Q, Wang C, Churchman GJ, Zhao L, Gong N, Yin K (2017) Clay mineralogy of altered tephra beds and facies correlation between the Permian-Triassic boundary stratigraphic sets, Guizhou, south China. Appl Clay Sci 143:10-21

30. Hong H, Li Z, Xue H, Zhu Y, Zhang K, Xiang S (2007) Oligocene clay mineralogy of the Linxia Basin: Evidence of Paleoclimatic evolution subsequent to the initial-stage uplift of the Tibetan Plateau. Clays Clay Minerals 55:491-503

31. Hong H, Wang C, Xu Y, Zhang K, Ke Y (2010) Paleoclimate Evolution of the Qinghai-Tibet Plateau since the Cenozoic. Earth Sci 35:728-736

32. Ingram BL, Sloan D (1992) Strontium isotopic composition of estuarine sediments as paleosalinity-paleoclimate indicator. Science 255:68-72

33. Jain M, Tandon SK (2003) Quaternary alluvial stratigraphy and palaeoclimatic reconstruction at the Thar margin. Curr Sci 84:1048-1055

34. Ji J, Zhang K, Clift PD, Zhuang G, Song B, Ke X, Xu Y (2017) High-resolution magnetostratigraphic study of the Paleogene-Neogene strata in the Northern Qaidam Basin: Implications for the growth of the Northeastern Tibetan Plateau. Gondwana Res 46:141

35. Jiang HJ, Ming-Yi HU, Zhong-Gui HU, Ling KE, Yan-Xia XU, Lian-Qian WU (2011) Sedimentary environment of Paleogene in Xihu Sag: Microfossil as the main foundation. Lithologic Reservoirs 23:74-78

36. Kai Q, Wang S, Liu S, Shi H (1982) Evaluation of salinity of lake water of tertiary of the Dongying depression. Acta Petrol Sinica 4:95-102

37. Li X, Zhang R, Zhang Z, Yan Q (2017) What enhanced the aridity in Eocene Asian inland: Global cooling or early Tibetan Plateau uplift? Palaeogeography Palaeoclimatology Palaeoecology 510:6-14

38. Liu Y, Song C, Meng Q, He P, Yang R, Huang R, Chen S, Wang D, Xing Z (2020) Paleoclimate change since the Miocene inferred from clay-mineral records of the Jiuquan Basin, NW China. Palaeogeography Palaeoclimatology Palaeoecology 550:109730

39. Liu Z, Trentesaux A, Clemens SC, Colin C, Wang P, Huang B, Boulay S (2003) Clay mineral assemblages in the northern South China Sea: implications for East Asian monsoon evolution over the past 2 million years. Mar Geol 201:133-146

40. Lu H, Xiong S (2009) Magnetostratigraphy of the Dahonggou section, northern Qaidam Basin and its bearing on Cenozoic tectonic evolution of the Qilian Shan and Altyn Tagh Fault. Earth Planetary ence Letters 288:539-550

41. Mclennan SM, Hemming SR, Mcdaniel DK, Hanson GN (1993) Geochemical approaches to sedimentation, provenance, and tectonics

42. Molnar P, Boos WR, Battisti DS (2010) Orographic Controls on Climate and Paleoclimate of Asia: Thermal and Mechanical Roles for the Tibetan Plateau. Annual Review of Earth Planetary ences 38:77-102

43. N. A, D. SN. (2020) Clay minerals and organic matter in shelf sediments off Coromandel Coast of India: Implications for provenance, transportation and depositional processes. Continental Shelf Research 198:104097

44. Nesbitt HW, Young GM (1982) Early Proterozoic climates and plate motions inferred from major element chemistry of lutites. Nature 299:715-717

45. Rodrigues IC, Mizusaki AMP, Lima LG, Maraschin AJ (2018) Comparative evolution of clay minerals in southern Paraná Basin (Brazil): Implications for triassic paleoclimate. J S Am Earth Sci 90:181-190

46. Rohling EJ (2007) Progress in paleosalinity: Overview and presentation of a new approach. Paleoceanography 22:768-771

47. Rongcai Z, Meiqing L (1999) Study on palaeosalinity of China 6 oil reservoir set in Ordos Basin. oil gas geology 20:20-25

48. Seward D (1978) Palaeosalinities and palaeotemperatures from carbon and oxygen isotopes of carbonate shells in three quaternary formations, Wanganui Basin, New Zealand. Palaeogeography Palaeoclimatology Palaeoecology 23:47-55

49. Singh SP, Singh SK, Bhushan R (2014) Dissolved Boron in the Tapi, Narmada and the Mandovi Estuaries, the Western Coast of India: Evidence for Conservative Behavior. Estuaries Coasts 37:1017-1027

50. Song B, Spicer RA, Zhang K, Ji J, Shi G (2020) Qaidam Basin leaf fossils show northeastern Tibet was high, wet and cool in the early Oligocene. Earth Planetary Science Letters 537:116-175

51. Song B, Zhang K, Lu J, Wang C, Sun YY, Xu Y (2013) The middle Eocene to early Miocene integrated sedimentary record in the Qaidam Basin and its implications for paleoclimate and early Tibetan Plateau uplift. Can J Earth Sci 50:183-196

52. Sun X, Wang P (2005) How old is the Asian monsoon system?-Palaeobotanical records from China. Palaeogeography Palaeoclimatology Palaeoecology 222:181-222

53. Sun Z, Yang Z, Pei J, Ge X, Wang X, Yang T, Li W, Yuan S (2005a) Magnetostratigraphy of Paleogene sediments from northern Qaidam Basin, China: Implications for tectonic uplift and block rotation in northern Tibetan plateau. Earth Planetary ence Letters 237:635-646

54. Sun Z, Yang Z, Pei J, Ge X, Wang X, Yang T, Li W, Yuan S (2005b) Magnetostratigraphy of Paleogene sediments from northern Qaidam Basin, China: Implications for tectonic uplift and block rotation in northern Tibetan plateau. Earth Planetary Science Letters 237:635-646

55. B.Price TWalkerC N (1963) Departure Curves for Computing Paleosalinity from Boron in Illites and Shales. Aapg Bulletin 47:833-841

56. Taheri M, Khormali F, Wang X, Amini A, Landi A, Wei H, Kehl M, Chen F (2019) Clay mineralogy and geochemistry of the Lower Pleistocene Loess in the Iranian Loess Plateau (Agh Band section) and implications for its provenance and paleoclimate change. Quatern Int 552:93-99

57. Veizer J, Lemieux J, Jones B, Gibling MR, Savelle J (1977) Sodium: Paleosalinity indicator in ancient carbonate rocks. Geology 5:177-179

58. Walker CT (1968) Evaluation of Boron as a Paleosalinity Indicator and its Application to Offshore Prospects. Aapg Bulletin 52:751-766

59. Wang Q, Song Y, Li Y (2020) Clay mineralogy of the upper Miocene-Pliocene red clay from the central Chinese Loess Plateau and its paleoclimate implications. Quatern Int 552:148-154

60. Wei W, Algeo TJ (2019) Elemental proxies for paleosalinity analysis of ancient shales and mudrocks. Geochimica Et Cosmochimica Acta

Page $9 / 14$ 
61. Wu C, Yan C, Li H, Tian G, Pan J (2013) Cenozoic tectonic evolution of the western Qaidam Basin and its constrain on the growth of the northern Tibetan Plateau. Acta Petrologica Sinica 29:2211-2222

62. Xiao G, Abels HA, Yao Z, Hilgen D (2010) Asian aridification linked to the first step of the Eocene-Oligocene Climate Transition (EOT) in obliquitydominated terrestrial records in Xining Basin, China. Journal of Earth Science

63. Xu G, Deconinck JF, Feng Q, Baudin F, Pellenard P, Shen J, Bruneau L (2016) Clay mineralogical characteristics at the Permian-Triassic Shangsi section and their paleoenvironmental and/or paleoclimatic significance. Palaeogeography Palaeoclimatology Palaeoecology 474:152-163

64. Xu H, Liu B, Wu F (2010) Spatial and temporal variations of Rb/Sr ratios of the bulk surface sediments in Lake Qinghai. Geochem Trans 11:1-8

65. Xue K, Junliang J, Kexin Z, Xiaohu K, Bowen S, Chaowen W (2013) Magnetostratigraphy and Anisotropy of Magnetic Susceptibility of the Lulehe Formation in the Northeastern Qaidam Basin. Acta Geol Sin 87:576-587

66. Yang R, Fan A, (Tom) AJVL, Han Z, Zavala C (2018) The influence of hyperpycnal flows on the salinity of deep-marine environments, and implications for the interpretation of marine facies. Marine Petroleum Geology 98:1-11

67. Ye C, Yang Y, Fang X, Zhang W (2016) Late Eocene clay boron-derived paleosalinity in the Qaidam Basin and its implications for regional tectonics and climate. Sed Geol 346:49-59

68. Zhang T, Fang X, Wang Y, Song C, Zhang W, Yan M, Han W, Zhang D (2018) Late Cenozoic tectonic activity of the Altyn Tagh range: Constraints from sedimentary records from the Western Qaidam Basin, NE Tibetan Plateau. Tectonophysics 737:40-56

69. Zhang W, Fang X, Song C, Appel E, Yan M, Wang Y (2013) Late Neogene magnetostratigraphy in the western Qaidam Basin (NE Tibetan Plateau) and its constraints on active tectonic uplift and progressive evolution of growth strata. Tectonophysics 599:107-116

70. Zhao L, Ji J, Chen J, Liu L, Chen Y, Balsam W (2005) Variations of illite/chlorite ratio in Chinese loess sections during the last glacial and interglacial cycle: Implications for monsoon reconstruction. Geophys Res Lett 32:242-257

71. Zheng R, Liu M (1999) Study on palaeosalinity of China 6 oil reservoir set in Ordos Basin. oil gas geology 20:20-25

\section{Figures}

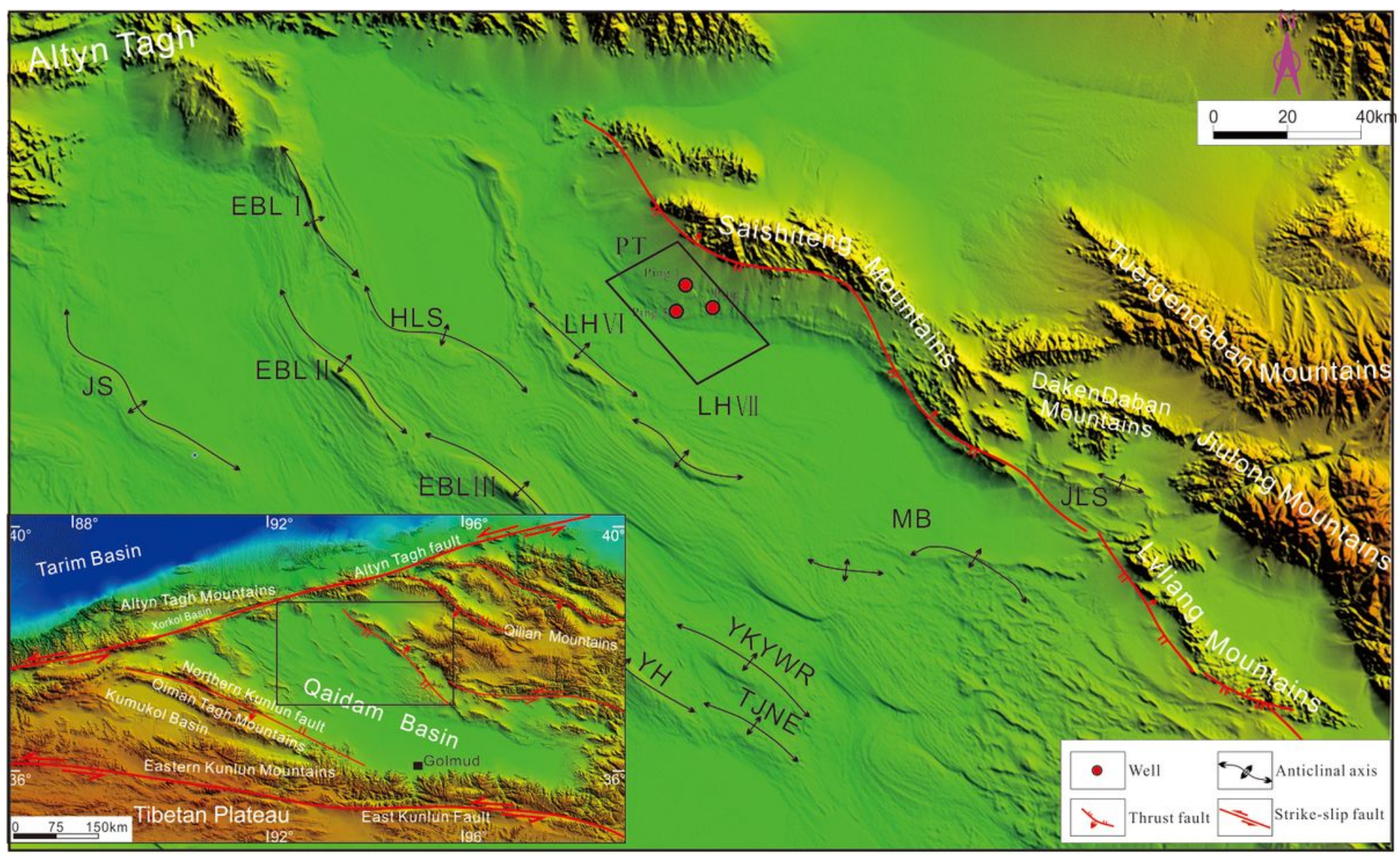

$\mathrm{JS}=$ Jianshan, EBLI = Eboliang I, EBL II = Eboliang II, EBL III = Eboliang III,

HLS = Hulushan, LH VI = Lenghu VI, LH VII = Lenghu VII, NBX = Nanbaxian, MB = Mabei, YKYWR $=$ Yikeyawuru, YH $=$ Yahu, TJNR $=$ Taijinaier. PT=Pingtai

Figure 1

Tectonic map of the northern margin of Qaidam Basi 

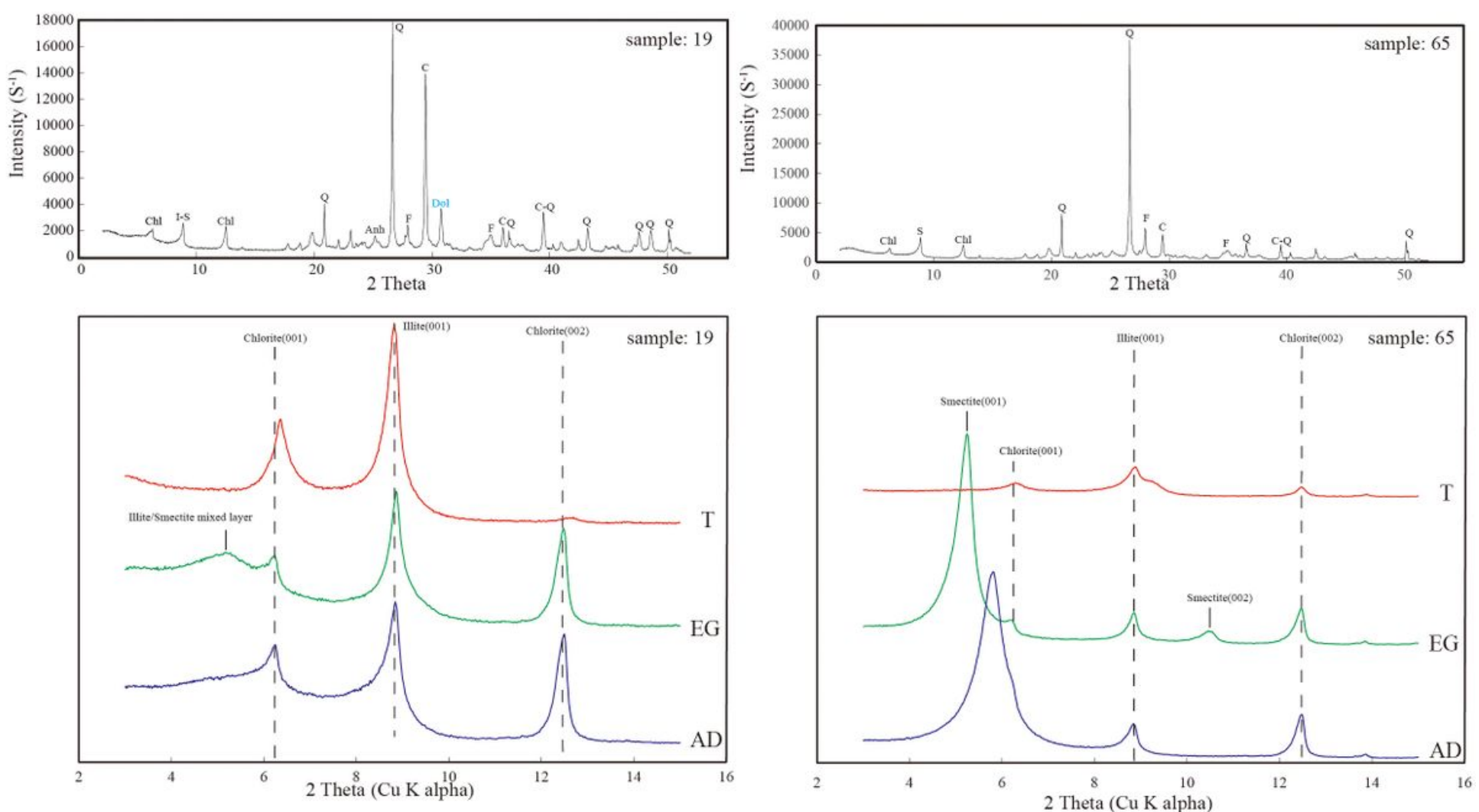

Figure 2

X-ray diffraction pattern of the typical samples. Abbreviations refer to minerals: Q-quartz; C-calcite; F-feldspar; K-kaolinite; I-S-illite and/or smectite; ChlChlorite; Anh- anhydrite; Dol- dolomite®AD: air-dried sample; EG:glycol-saturated sample; T: heated sample. 


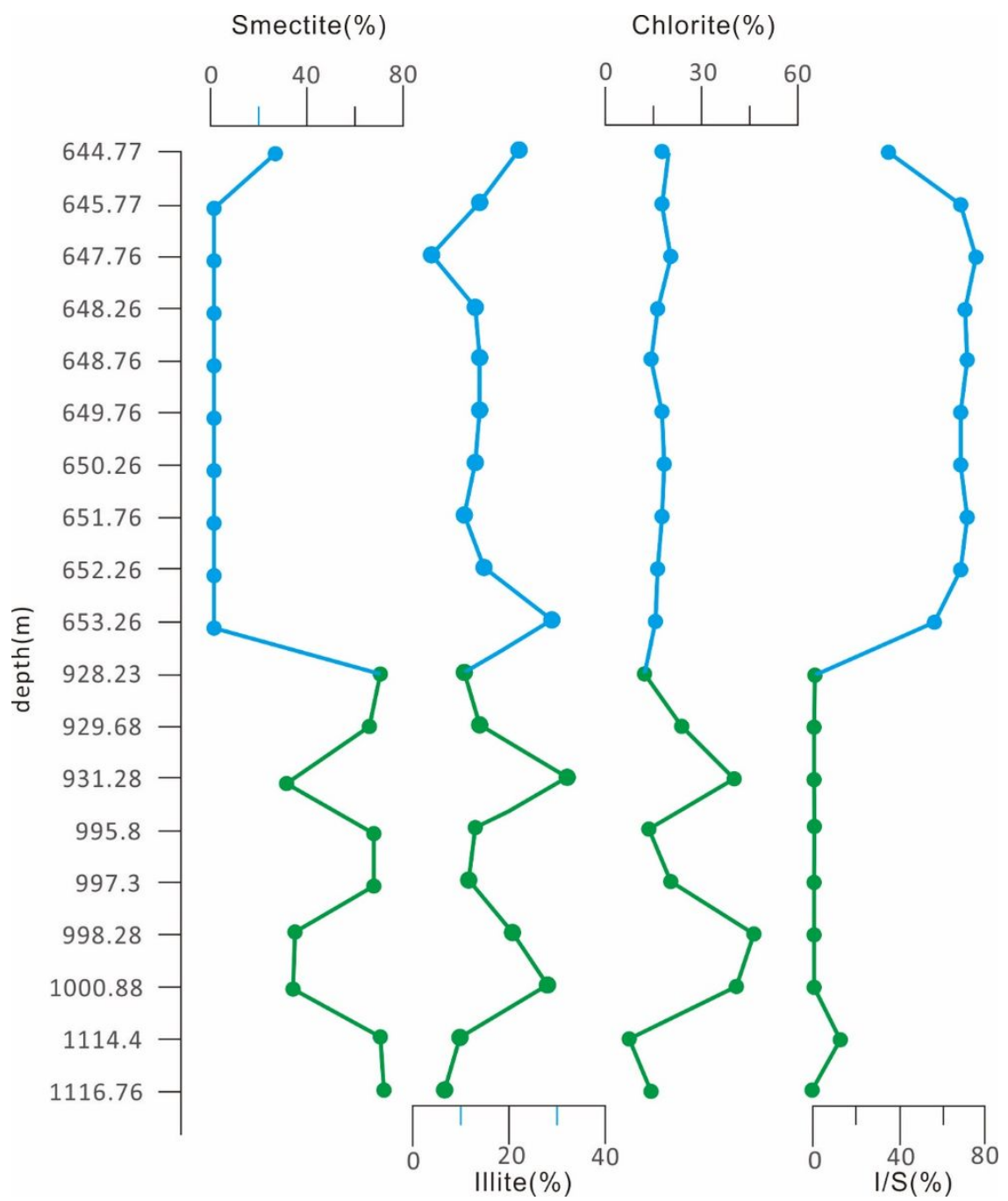

Figure 3

Relative content of clay minerals 


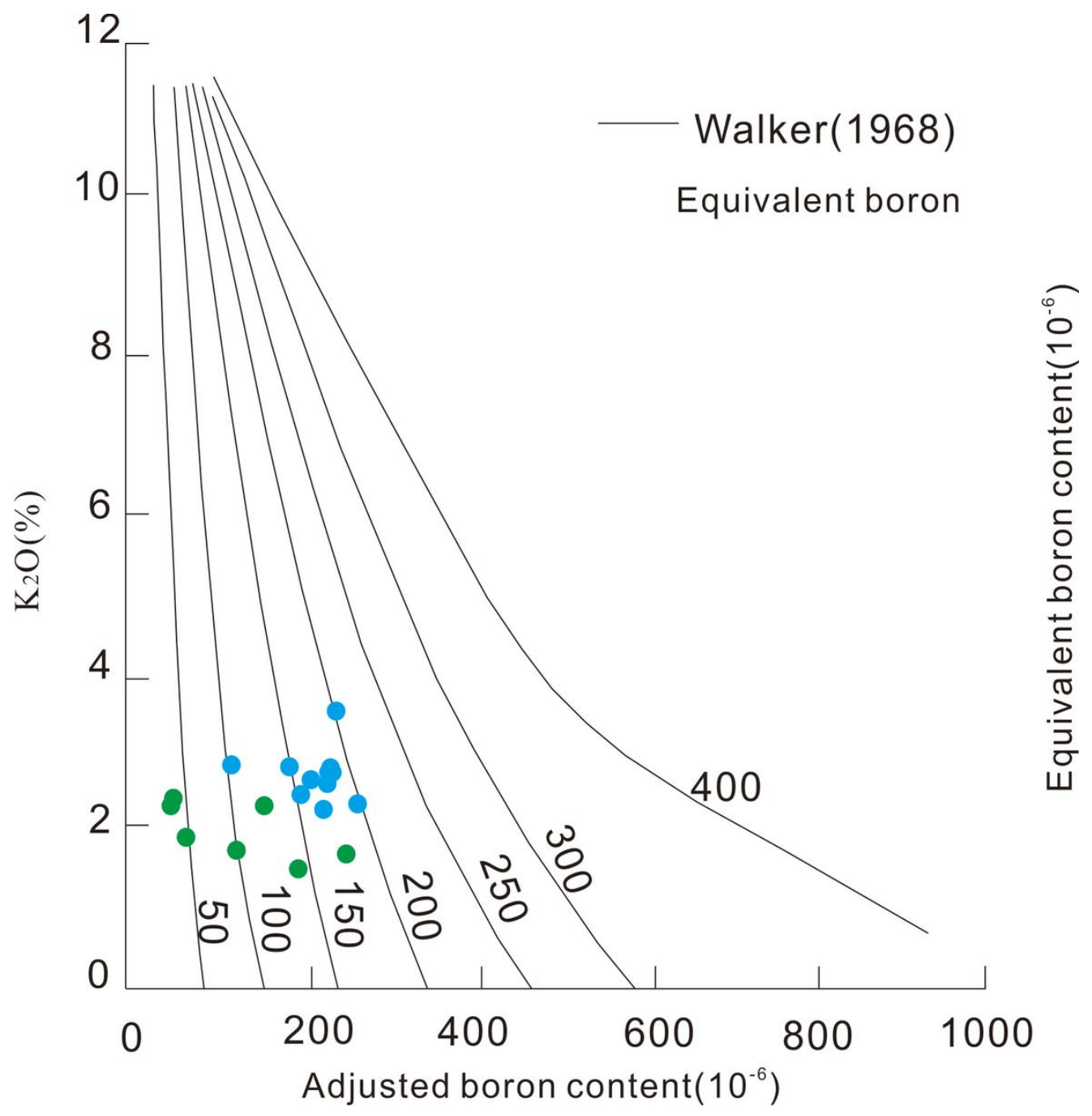

Figure 4
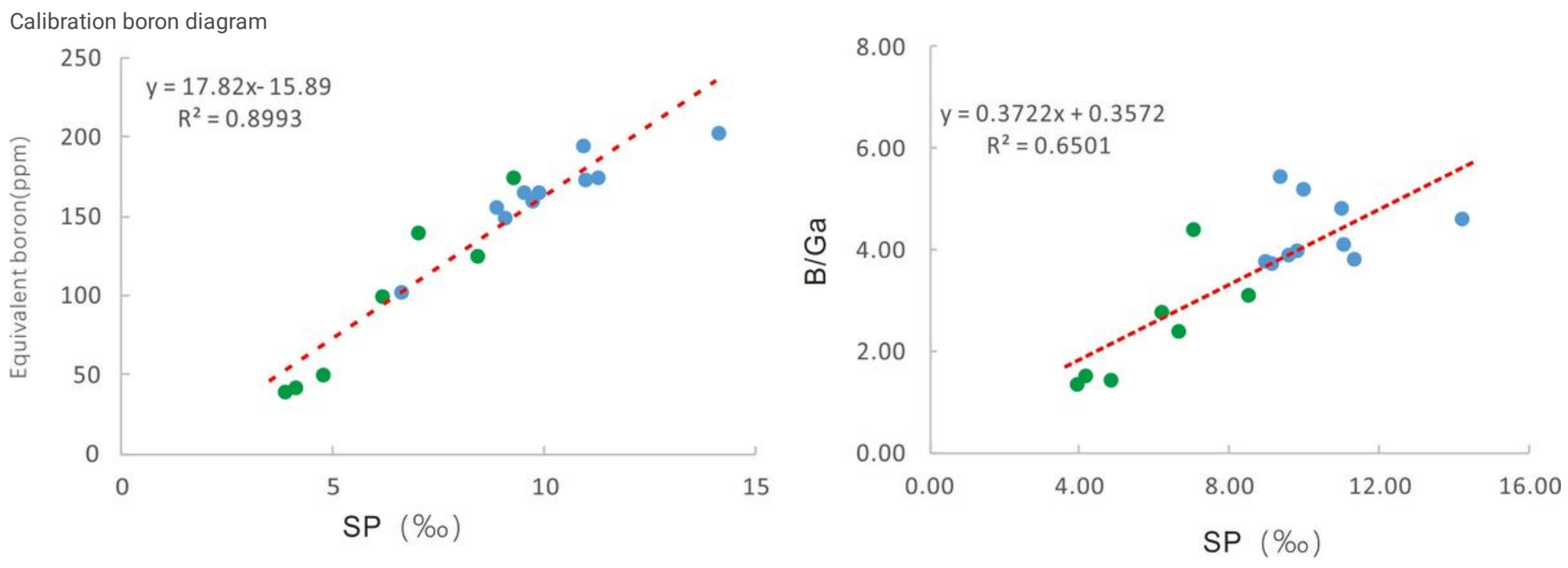

Figure 5

Correlation between paleosalinity and $\mathrm{B}, \mathrm{B} / \mathrm{Ga}$ 


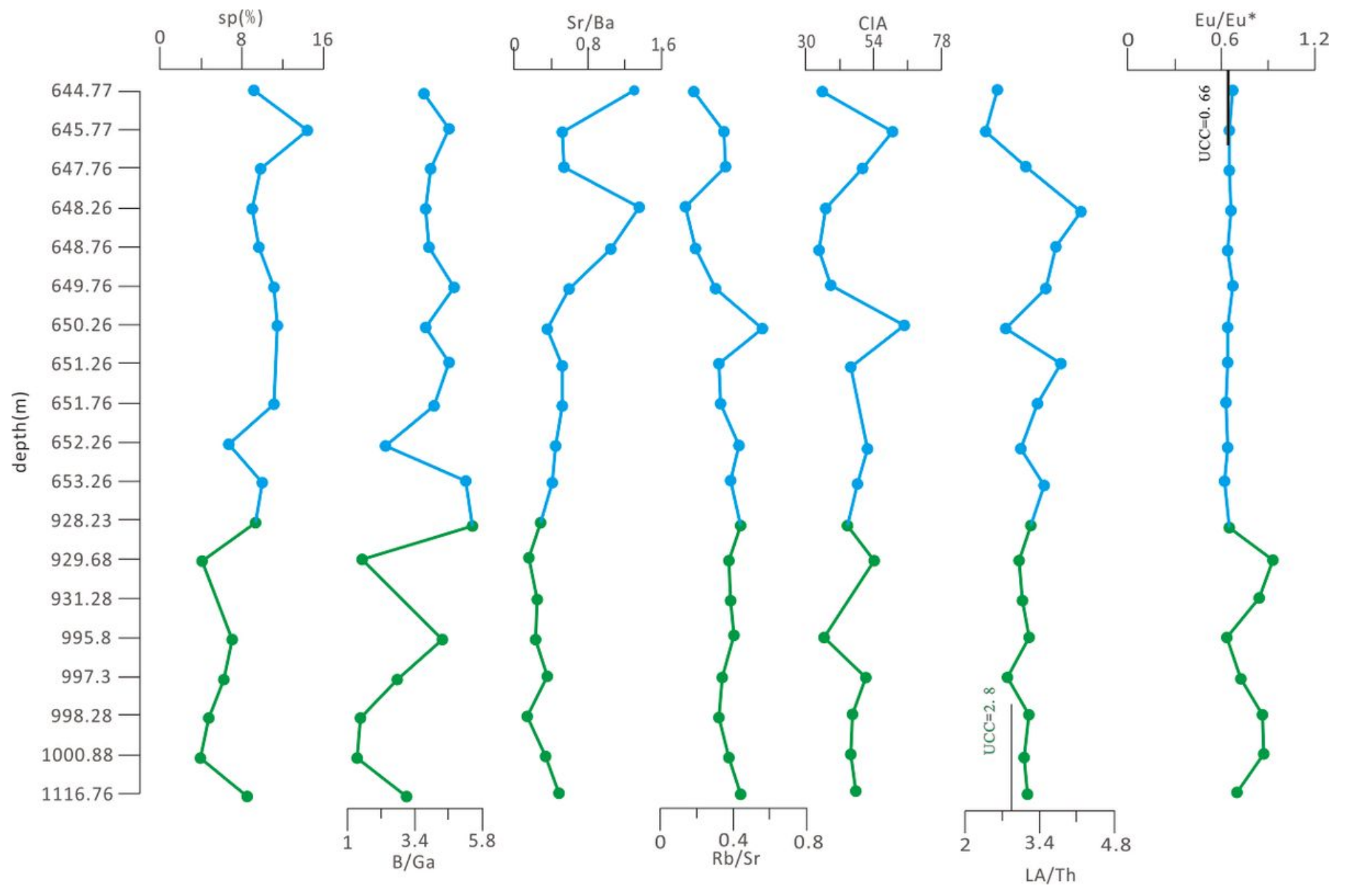

Figure 6

Ratio of paleoclimatology to paleosalinity 